\title{
Prediction of Retention Level and Mechanical Strength of Plywood Treated with Fire Retardant Chemicals by Artificial Neural Networks
}

\author{
Şükrü ÖZSAHİN ${ }^{1} \quad$ Aydın DEMİR $^{2^{*}} \quad$ İsmail AYDIN ${ }^{2}$ \\ ${ }^{1}$ Karadeniz Technical University, Department of Industrial Engineering Kanuni Campus, Trabzon/Türkiye \\ 2* Karadeniz Technical University, Department of Forest Industry Engineering Kanuni Campus, Trabzon/Türkiye
}

How to cite: Özşahin, Ş., Demir, A. \& Aydın, I. (2020). Prediction of retention level and mechanical strength of plywood treated with fire retardant chemicals by artificial neural networks. J. Anatolian Env. and Anim. Sciences, 5(5), 785-792.

Atıf yapmak için: Özşahin, Ş., Demir, A. \& Aydın, İ. (2020). Yangın geciktirici kimyasallarla emprenye edilmiş kontrplakların retensiyon miktarları ve mekanik dirençlerinin yapay sinir ağları ile tahmin edilmesi. Anadolu Çev. ve Hay. Dergisi, 5(5), 785-792.

iD: https://orcid.org/0000-0001-8216-0048

*iD : https://orcid.org/0000-0003-4060-2578

(iD): https://orcid.org/0000-0003-0152-7501

*Corresponding author's:

Aydın DEMIR

Karadeniz Technical University, Department

of Industrial Engineering Kanuni Campus,

Trabzon, Turkey.

$\triangle$ : aydindemir@ktu.edu.tr

Mobile telephone: +90 (538) 7903934

Telephone : $+90(462) 3771560$

Fax : +90(462) 3257499
Abstract: The treatment with fire-retardant chemicals is the most effective process to protect wood and wood-based products from fire is. Therefore, use of fire-retardant chemicals has been increased. However, the fire-retardant chemicals have an effect on other physical, mechanical and some technological properties of the materials treated with them. In this study, firstly, the retention level prediction model was developed with the artificial neural network (ANN) to examine the effects of wood species and concentration aqueous solution on the retention levels of veneers. Then, the effects of wood species, concentration aqueous solution and retention level on the mechanical properties of plywood were investigated with the mechanical strength prediction model developed with ANN. The prediction models with the best performance were determined by statistical and graphical comparisons. It has been observed that ANN models yielded very satisfactory results with acceptable deviations. As a result, the findings of this study could be employed effectively into the forest products industry to reduce time, energy and cost for empirical investigations.

Keywords: Artificial Neural Network, concentration, fire-retardant, mechanical properties, plywood, retention level.

\section{Yangın Geciktirici Kimyasallarla Emprenye Edilmiş Kontrplakların Retensiyon Miktarları ve Mekanik Dirençlerinin Yapay Sinir Ağları ile Tahmin Edilmesi}

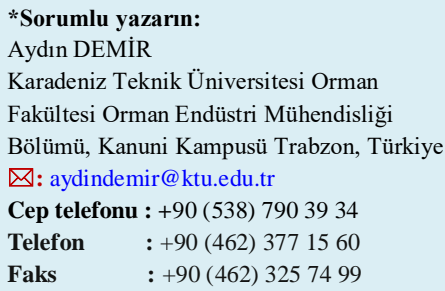

Öz: Yangın geciktirici kimyasallar ile emprenye işlemi, ahşap ve ahşap esaslı ürünlerin yangından korunmasında çok etkili bir işlemdir. Bu yüzden, yangın geciktirici kimyasalların kullanımı tüm dünyada artmaktadır. Ancak, yangın geciktirici kimyasallar, uygulanmış oldukları malzemelerin fiziksel, mekanik ve diğer bazı teknolojik özellikleri üzerinde bir etkiye neden olmaktadır. Bu çalışmada ilk olarak, ağaç türlerinin ve konsantrasyon miktarlarının kaplamaların retensiyon miktarları üzerindeki etkilerini incelemek için yapay sinir ağı (YSA) ile retensiyon miktarı tahmin modeli geliştirilmiştir. Daha sonra YSA ile geliştirilen mekanik direnç tahmin modeli ile ağaç türleri, konsantrasyon miktarları ve retensiyon miktarlarının kontrplağın mekanik özelliklerine etkileri araştırılmıştır. En iyi performansa sahip tahmin modelleri, istatistiksel ve grafiksel karşılaştırmalarla belirlenmiştir. YSA modellerinin kabul edilebilir sapmalarla oldukça tatmin edici sonuçlar verdiği görülmüştür. Sonuç olarak, bu çalıșmanın bulguları, deneysel araştırmalar için zaman, enerji ve maliyeti azaltmak için orman ürünleri endüstrisinde etkin bir şekilde kullanılabilecektir.

Anahtar kelimeler: Konsantrasyon, kontrplak, mekanik özellikler, retensiyon miktarı, yangın geciktirici, yapay sinir ağları. 


\section{INTRODUCTION}

Wood and wood-based panels have long used a material in the construction industry because they have a great durability, high strength and versatility (Stevens et al., 2006). Plywood, being a wood-based product, one of the most important building and furniture materials (Fateh et al., 2013). Plywood has some advantages when compared to solid wood and other wood panels. Physical properties of plywood are better than other wood panels. Bending strength and screw holding capacity of plywood is very high, and it is resistant to deformation disorders such as distortion or twisting. Since plywood has a homogeneous structure, its shrinkage and expansion are much less than solid wood. There are some unfavorable characteristics of the plywood similar to wood and other wood-based composite panels. It can be combusted easily, and this is one of the undesired characteristics of plywood (Ozkaya et al., 2007).

The flammability and combustibility properties of such a solid material can be reduced recommended several treatments (Fateh et al., 2013). The treatment with fireretardant chemicals is the most effective process to protect wood and wood-based products from fire is. Therefore, use of fire-retardant chemicals has been increased. It has also risen due to awareness of environmental protection and consumer safety, requirement standards to flame retardants have been raised accordingly. Moreover, capability and properties of fire-retardant chemicals such as being harmless to human, animals, and plants and less release of smoke and toxic gases when burned are important parameters for consumer to select a fire-retardant chemical. It was also shown the fire-retardant chemicals have an effect on other physical, mechanical and some technological properties of the materials treated with them. Inorganic based fire-retardant chemicals are extensively used in forest industry because they have both good thermal stability, less release of smoke, corrosive toxic gases and less strength loss (Yao et al., 2012; He et al., 2014).

Determination of the optimum concentration of aqueous solution and retention level without further loss of mechanical strength is also very important from industrial view point. For this aim, a lot of concentration values need to be tested to determine the optimum values that cause the loss of much time and energy and high costs. Therefore, it is important to find more economic methods providing desirable results concerning technological properties (Demirkir et al., 2013). Artificial neural networks (ANNs) have been widely used in the field of wood (Esteban et al., 2011). The neural network most commonly used is the multilayer perception, whose nature as a universal function approximation makes it a powerful tool for modelling complex relations between variables (Fernandez et al., 2012). ANNs are capable of processing information in a parallel distributed manner, learning complex cause-andeffect relationships between input and output data, dealing with nonlinear problems, generalizing from known tasks or examples to unknown tasks. ANNs are good for tasks involving incomplete data sets, fuzzy or incomplete information, and for highly complex and ill-defined problems, where people usually decide on an intuitional basis. Moreover, they can be faster, cheaper and more adaptable than traditional methods (Ceylan, 2008; Ozsahin and Aydin, 2014).

In this study, firstly, the retention level prediction model was developed with the artificial neural network (ANN) to examine the effects of wood species and concentration aqueous solution on the retention levels of veneers. Then, the effects of wood species, concentration aqueous solution and retention level on the mechanical properties of plywood were investigated with the mechanical strength prediction model developed with ANN.

\section{MATERIALS AND METHOD}

Data Collection: In this experimental study, 2 mm-thick rotary cut veneers with the dimensions of 500 $\mathrm{mm}$ by $500 \mathrm{~mm}$ were obtained from poplar (Populus deltoides), alder (Alnus glutinosa subsp. barbata) and Scots pine (Pinus sylvestris L.) logs. While the alder and poplar veneers were manufactured from freshly cut logs, Scots pine logs were steamed for $12 \mathrm{~h}$ before veneer production. The horizontal opening between knife and nosebar was $85 \%$ of the veneer thickness, and the vertical opening was $0.5 \mathrm{~mm}$ in rotary cutting process. The veneers were then dried to $6-8 \%$ moisture content in a veneer dryer. After drying, veneer sheets were treated with some fire-retardant chemicals. For this aim, 5, 7 and $10 \%$ aqueous solutions of zinc borate, monoammonium phosphate (MAP) and ammonium sulphate were used. The veneers were subjected to re-drying process at $110^{\circ} \mathrm{C}$ after they immersed in the fire-retardant solutions for $20 \mathrm{~min}$. The retention level for each treatment solution was calculated with the following equation.

$\mathrm{R}=\frac{\mathrm{G} \times \mathrm{C}}{\mathrm{V}} \times 10 \mathrm{~kg} / \mathrm{m}^{3}$

$$
\begin{aligned}
& \text { Where } \\
& \mathrm{R}=\text { Retention level }\left(\mathrm{kg} / \mathrm{m}^{3}\right) \\
& \mathrm{G}=\text { treatment solution absorbed by the sample }(\mathrm{g}) \\
& \mathrm{C}=\text { preservative or preservative solution in } 100 \mathrm{~g} \text { treatment solution. } \\
& \mathrm{V}=\text { volume of sample in } \mathrm{cm}^{3}
\end{aligned}
$$

Three-ply-plywood panels with $6 \mathrm{~mm}$ thick were manufactured by using urea formaldehyde resin. The veneer sheets were conditioned to approximately $5-7 \%$ 
moisture content in an acclimatization chamber before gluing. The glue mixture was applied at a rate of $160 \mathrm{~g} / \mathrm{m}^{2}$ to the single surface of veneer by using a four-roller glue spreader. Hot press pressure was $12 \mathrm{~kg} / \mathrm{cm}^{2}$ for alder and 8 $\mathrm{kg} / \mathrm{cm}^{2}$ for scots pine and poplar panels while hot pressing time and temperature were $6 \mathrm{~min}$ and $110^{\circ} \mathrm{C}$, respectively. Two replicate panels were manufactured for each test groups.

The bonding strength of plywood panels was determined according to EN 314-1 (1998) with a universal testing machine. Samples manufactured with UF resin were tested after immersion in water at $20^{\circ} \mathrm{C}$ for $24 \mathrm{~h}$. The bending strength and modulus of elasticity of plywood panels was determined according to EN 310 (1993) with a universal testing machine.

Artificial Neural Network (ANN) Analysis: In this study, the retention level and mechanical strength values of plywood were modelled by ANN approach using the data obtained from the literature. First, the change in retention level was modelled depending on the wood species and concentration of aqueous solution. Then, modelling of the change in mechanical strength values based on wood species, concentration of aqueous solution and retention level values was carried out. The proposed ANN models were designed by software developed using the MATLAB Neural Network Toolbox. The data were obtained from the experimental study. In order to examine the effects of related variables on retention level and mechanical strength values; the experimental data were randomly and homogeneously grouped as training and test data, different data sets were created and used to train ANNs. Among these data, 18 samples were selected for ANN training process, while the remaining 9 samples were used to verify the generalization capability of ANN. The data sets used in the training and prediction models are shown in Table 1 and Table 2. The retention level and mechanical strength values results obtained experimentally also presented in Table 1 and Table 2, respectively.

The obtained predicted values as a result of the testing process were compared with the real (measured) values. The models providing the best prediction values with respect to the root mean-square error (RMSE) ratio, calculated with Eq. 2, the mean absolute percentage error (MAPE) ratio, calculated with Eq. 3 and coefficient of determination $\left(\mathrm{R}^{2}\right)$ with Eq. 4 was chosen as the prediction models.

$$
\begin{aligned}
& \text { RMSE }=\sqrt{\frac{1}{N} \sum_{i=1}^{N}\left(t_{i}-t d_{i}\right)^{2}} \\
& \text { MAPE }=\frac{1}{N}\left(\sum_{i=1}^{N}\left[\left|\frac{t_{i}-t d_{i}}{t_{i}}\right|\right]\right) \times 100
\end{aligned}
$$

$$
\mathrm{R}^{2}=1-\frac{\sum_{i=1}^{N}\left(t_{i}-t d_{i}\right)^{2}}{\sum_{i=1}^{N}\left(t_{i}-\bar{t}\right)^{2}}
$$

In Equations 2, 3 and 4, $t i$ is the actual output values, $t d i$ is the neural network predicted values, and $N$ is the number of objects.

Table 1. Training and testing data set and retention level prediction models results.

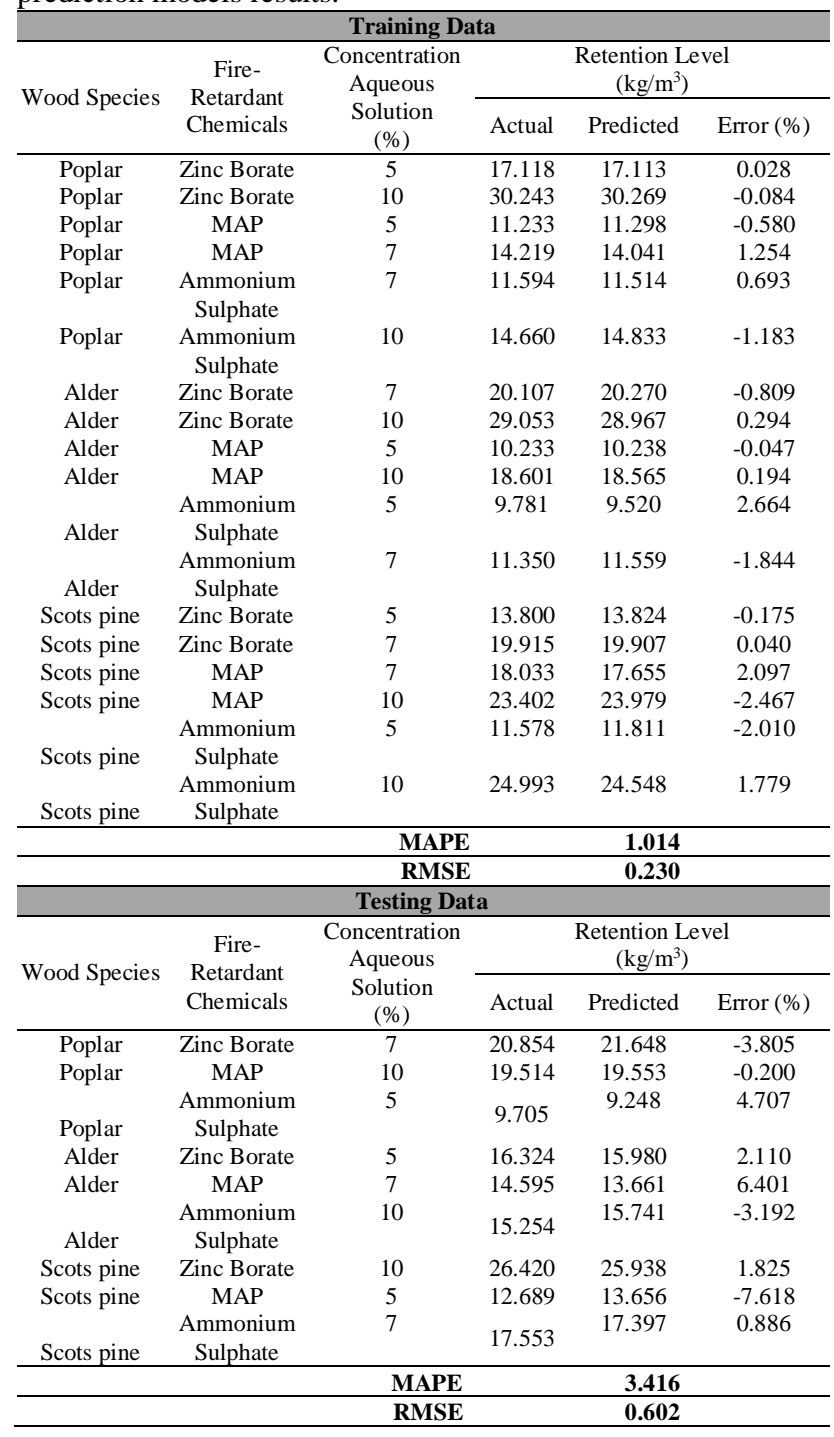

Figure 1 shows the ANN models containing one input layer, one or two hidden layers and one output layer. The selected ANN models represent the prediction models that produced the closest values to the measured values for the retention level, bonding strength, bending strength and modulus of elasticity. First, the wood species and concentration of aqueous solution were used as the input variables, while the retention level values were used as the output variable in the ANN models. 
Table 2. Training and testing data set and mechanical strength prediction models results.

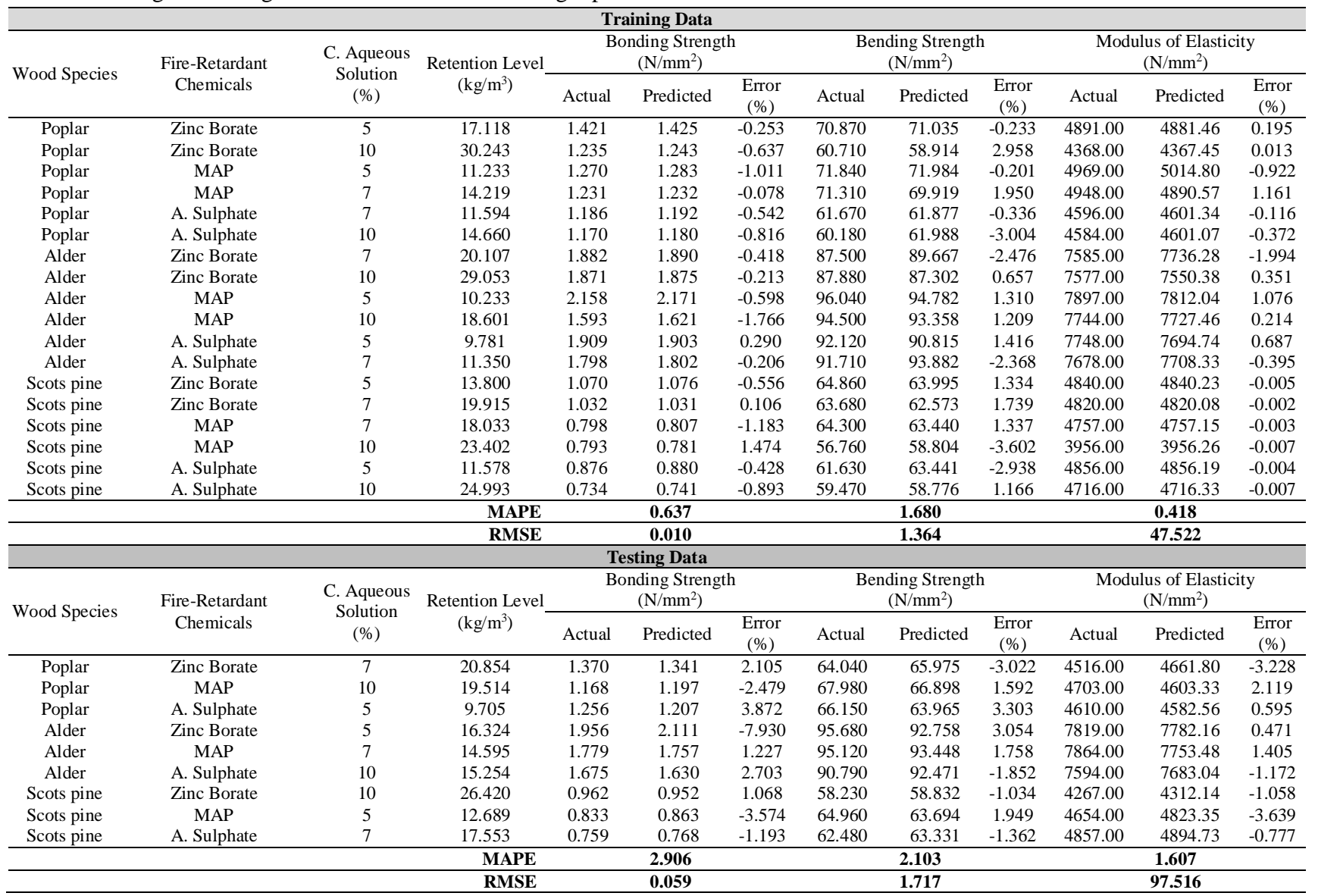

The processing element numbers (neurons) of the two hidden layers were 3-3 (first layer-second layer) for the models in Figure 1. Then, the wood species, concentration of aqueous solution and retention level were used as the input variables, while the bonding strength, bending strength and modulus of elasticity were used as the output variable in the ANN models. The processing element numbers (neurons) of the two hidden layers were 3-3 (first layer-second layer), 3 and 2-3 (first layersecond layer) for the models in Figure 1.
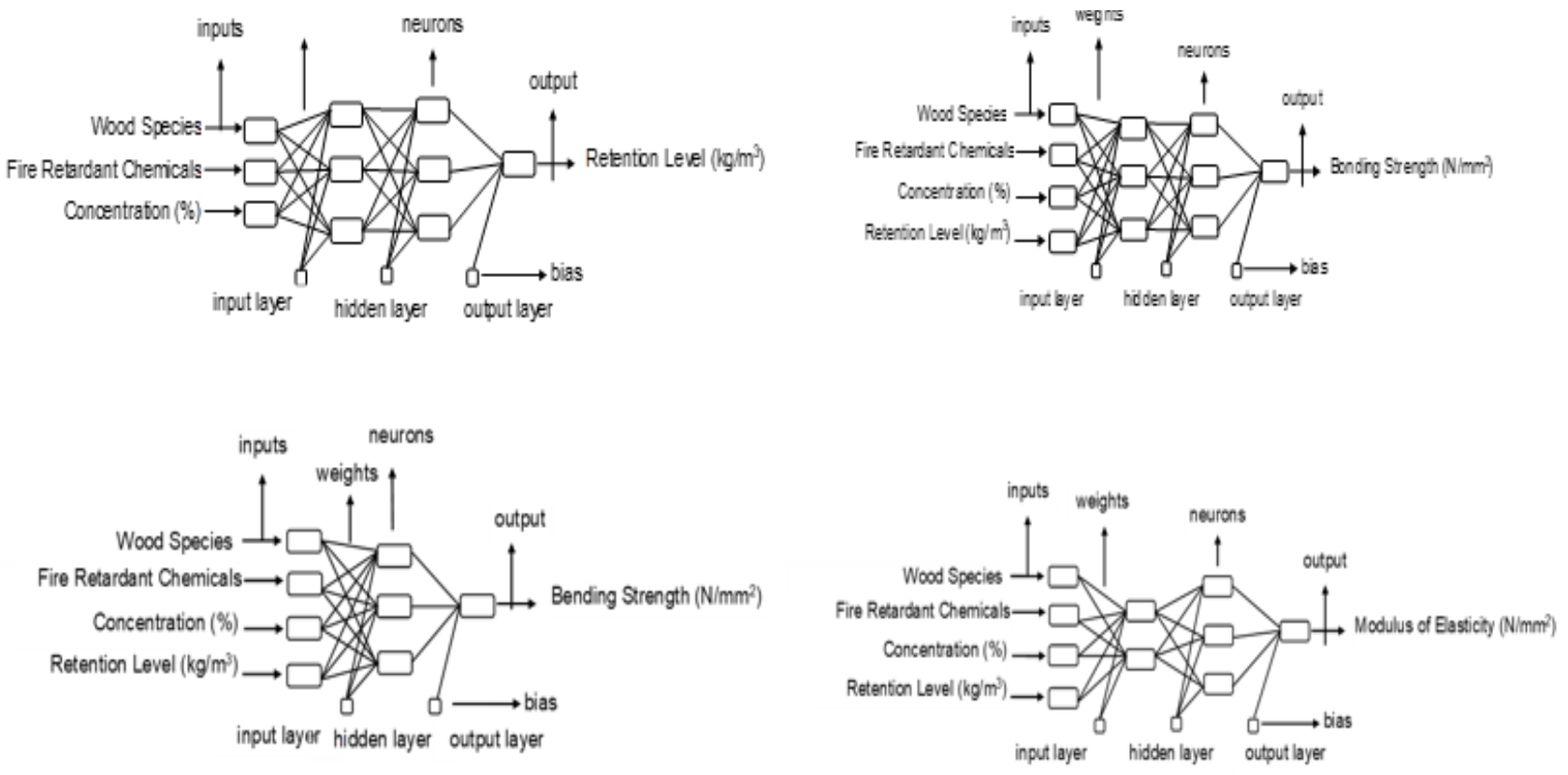

Figure 1. The ANN architecture selected as the prediction models. 
A feed forward and back propagation multilayer ANN was used for solving problems, and the network training and testing was carried out using the MATLAB software package. In this study, the hyperbolic tangent sigmoid function (tansig) and the linear transfer function (purelin) were used as the activation transfer functions, the levenberg marquardt algorithm (trainlm) was used as the training algorithm, the gradient descent with a momentum back propagation algorithm (traingdm) was used as the learning rule, and the mean square error (MSE) with Eq. 5 was used as the performance function.

$$
\operatorname{MSE}=\frac{1}{N} \sum_{i=1}^{N}\left(t_{i}-t d_{i}\right)^{2}
$$

Where, $t_{i}$ is the actual output (targeted values), $t d_{i}$ is the neural network output (predicted values), and $N$ is the total number of training patterns. To ensure an equal contribution of each parameter in the models, the training and test were normalized (-1, 1 range) due to the use of the hyperbolic tangent sigmoid function in the models and network, which allowed the data to be translated into the original value, with a reverse normalizing process for the interpretation of the results. The normalization (scaling) operations were carried out by using Eq. 6 .

$$
X_{\text {norm }}=2 \times \frac{X-X_{\min }}{X_{\text {max }}-X_{\min }}-1
$$

Where, $X_{\text {norm }}$ is the normalized value of a variable $X$ (real value of the variable), and $X_{\max }$ and $X_{\min }$ are the maximum and minimum values of $X$, respectively.

\section{RESULTS AND DISCUSSION}

ANN models were trained and tested with the data obtained from the experimental results of Demir et al. (2016). Change of retention level depending on the wood species and concentration were modelled with obtained network parameters. The amount of error variation depending on iteration of the selected ANN was shown in Figure 2. In addition, changes of bonding strength, bending strength and modulus of elasticity depending on the wood species, concentration and retention level were modelled with obtained network parameters. The amount of error variation depending on iteration of the selected ANN was shown in Figure 2. The best training performance was 0.00049989 in the 154th iteration for retention level, 0.00019427 in the 14th iteration for bonding strength, 0.004826 in the 19 th iteration for bending strength, 0.00058161 in the 500th iteration for modulus of elasticity.

Figure 3 and 4 show the relationship between the real values and calculated values obtained by the prediction models. The comparative plots of these values are given in Figure 5.
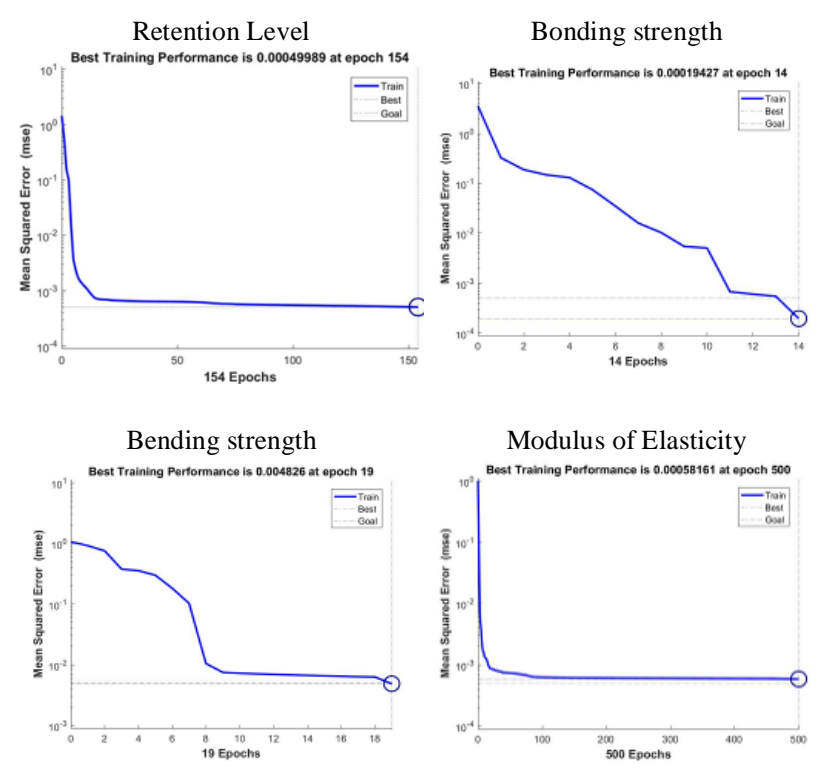

Figure 2. A plot of error variation depending on iteration of the ANNs.
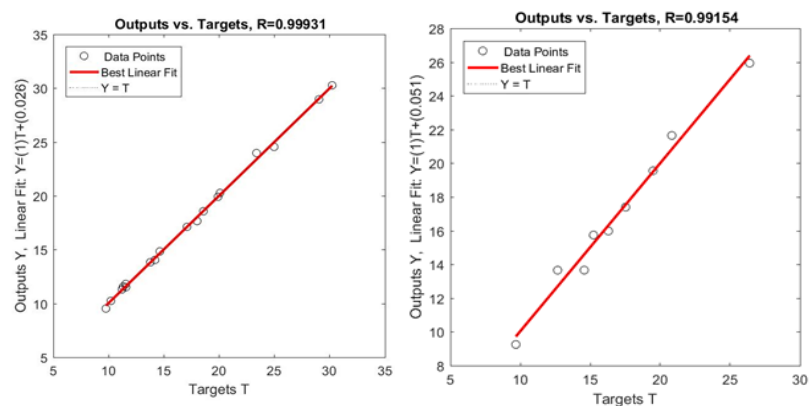

Figure 3. The relationship between experimental results of retention level and ANN predicted results.

In order to assess the validity of the networks and their accuracy, it is often useful to perform regression analysis between the network response and the corresponding target. The regression curves of the output variables for the experiment and ANN data set (training and testing) are shown in Figure 3 (retention level, training $\mathrm{R}=0.99931$; testing $\mathrm{R}=0.99154$ ) and Figure 4 (bonding strength, training $\mathrm{R}=0.99983$; testing $\mathrm{R}=0.99081$, bending strength, training $\mathrm{R}=0.99506$; testing $\mathrm{R}=$ 0.99371, modulus of elasticity, training $\mathrm{R}=0.99818$; testing $\mathrm{R}=0.99946)$. As the correlation coefficients approach 1, prediction accuracy increases and indicates good agreement between the experimental results and the models prediction. This value supports the applicability of using ANNs in the present study.

Comparisons of the results between the outcomes of ANN modelling and experimental values for the retention level, bonding strength, bending strength and modulus of elasticity values are plotted in Figure 5. The results of graphic comparisons showed similarities between the experimental study and the ANN models and supported the reliability of the models. 

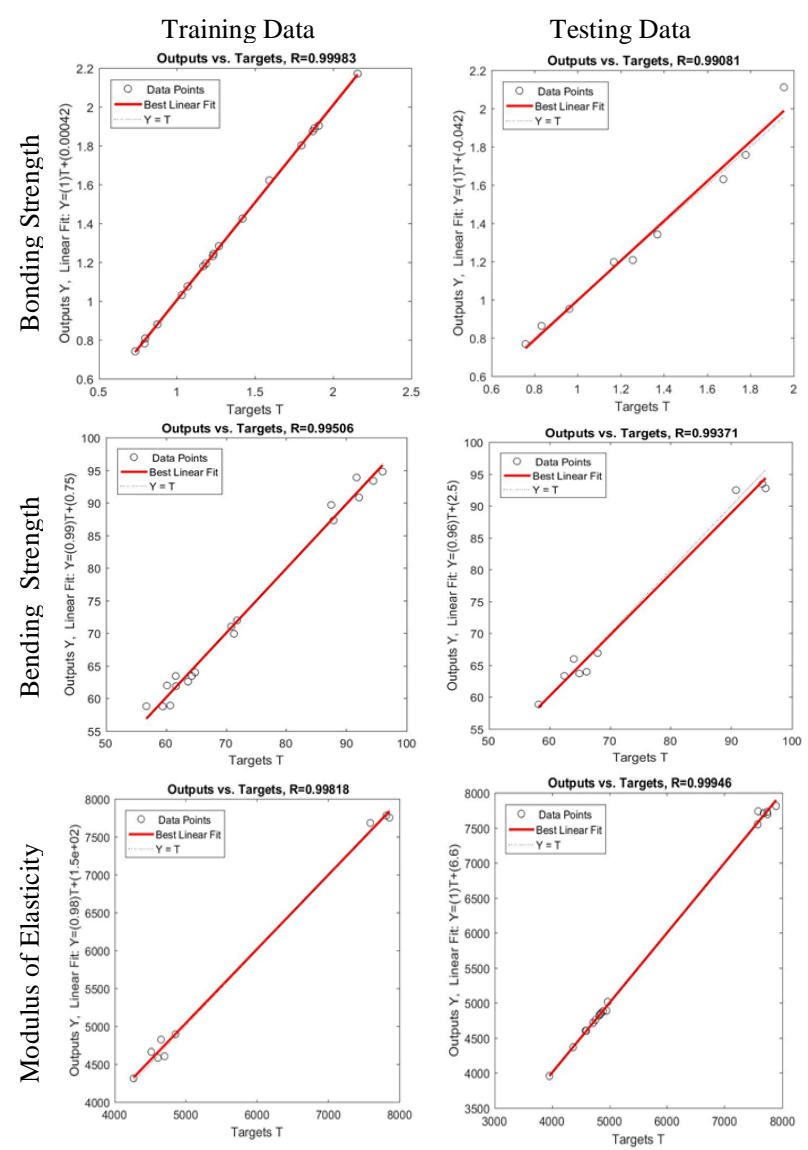

Figure 4. The relationship between experimental results of mechanical strength and ANN predicted results.

The results indicate a consistent agreement between the outcomes of the ANN modelling and the experimental results. MAPE was used to evaluate the performance of the proposed ANN in the prediction technique. The maximum absolute percentage errors (MAPE) for retention level, bonding strength, bending strength and modulus of elasticity were 1.014, 0.637, 1.680 and $0.418 \%$ for training and 3.416, 2.906, 2.103 and 1.607 $\%$ for testing, respectively. These levels of error are satisfactory for the retention level, bonding strength, bending strength and modulus of elasticity. As seen from the results, the ANN approach has a sufficient accuracy rate for the prediction of retention level, bonding strength, bending strength and modulus of elasticity values of plywood.

The intermediate values not obtained from the experimental study for retention level, bonding strength, bending strength and modulus of elasticity were predicted from the designed ANN modelling. The retention level, bonding strength, bending strength and modulus of elasticity values predicted by the ANN models for different concentration of aqueous solution are shown in Figure 6, 7, 8 and 9
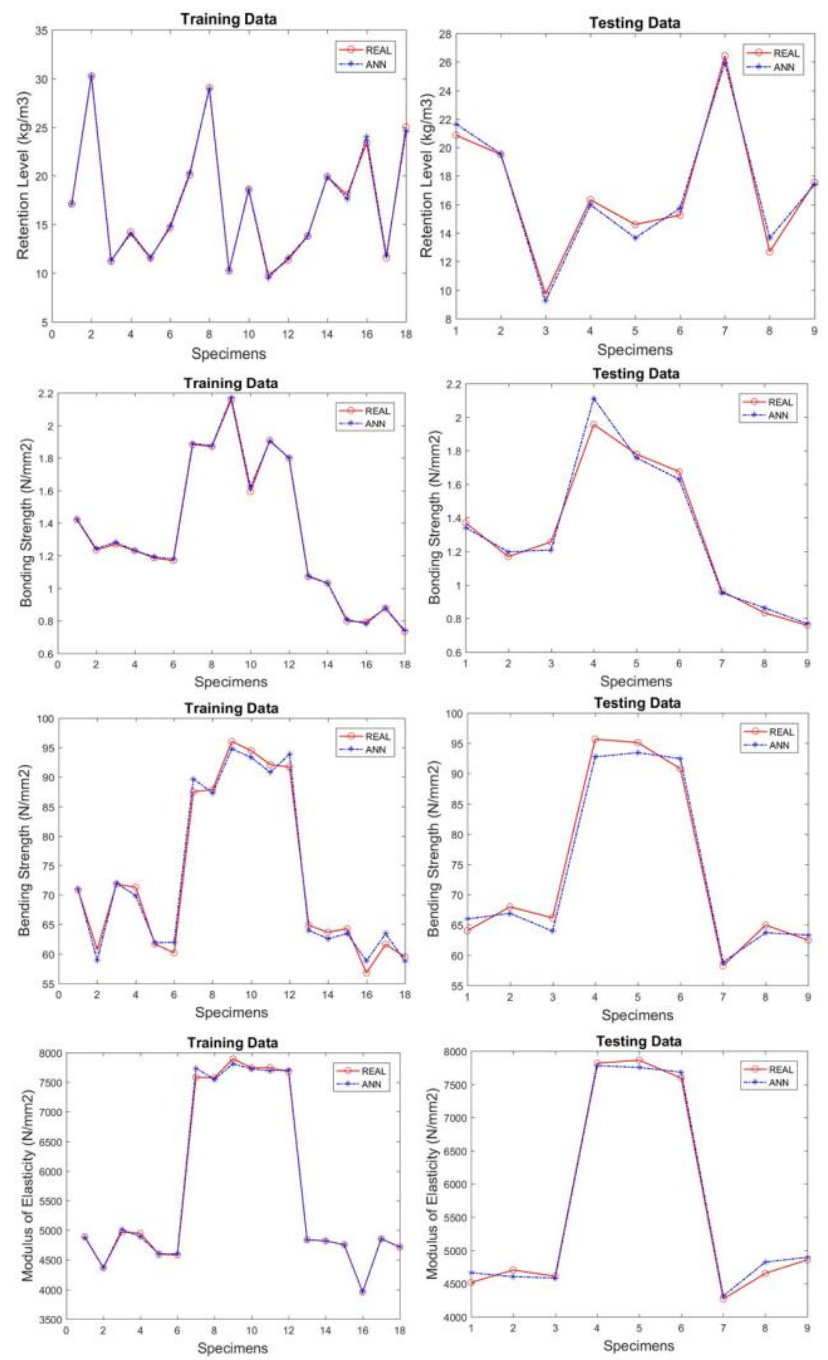

Figure 5. The comparison of the real and calculated values.

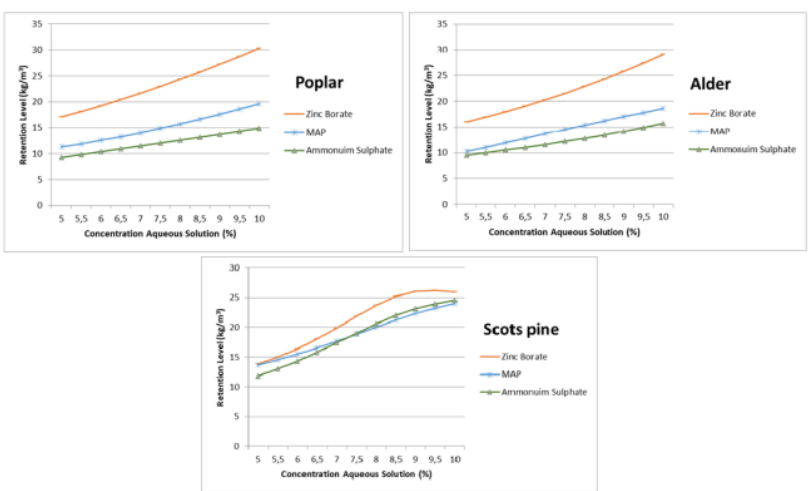

Figure 6. The change of retention level with increasing concentration of aqueous solution.

The retention level increased with increasing concentration aqueous solution according to Figure 6 . Among the fire-retardant chemicals, zinc borate caused more increase in retention levels than the other chemicals for all of wood species. In the first model, the retention levels estimated depending on the concentration values and in the second model the mechanical strength values were estimated. As can be seen Figures 7-9, generally, the mechanical properties of the panels can be adversely 
influenced by increased concentrations of fire-retardants. In literature, it was stated that the reasons for the reduction in mechanical strength of fire-retardant plywood could be related to the acidity of fire-retardant could influence the strength of the veneers; The poor compatibility between fire-retardant and UF adhesive and the fast curing rate of the UF adhesive, accelerated by fire-retardant, could, theoretically, prevent a direct and effective contact between the veneer and the UF adhesive, and hence affect the penetration of UF adhesive into the veneer (Cheng \& Wang, 2011). The second drying process performed after the impregnation may also contributed to decrease in shear strength. Aydin (2004) indicated that the impregnation material layer in the form of crystal remaining on the veneer surface after drying affected adversely wettability with glue and so the mechanical strength values decreased. Among the fire-retardant chemicals, zinc borate generally caused less decrease in bonding strength than the other chemicals for all of wood species. MAP generally caused less decrease in bending strength and modulus of elasticity than the other chemicals for all of wood species. However, the less decrease for modulus of elasticity values of Scots pine panels was obtain from ammonium sulphate.

The different changes of mechanical properties were determined according to concentration of fireretardants in the ANN models. For example, while the bending strength values of alder plywood treated with ammonium sulphate showed a slight increase up to $7.5 \%$ concentration, there was a slight increase in bending resistance up to $6 \%$ concentration in the treatment process with MAP. It is seen that the bending strength values of scots pine plywood remain almost constant up to $8 \%$ in the treatment process with ammonium sulphate, $7.5 \%$ in the treatment with MAP and $6.5 \%$ in the treatment with zinc borate (Figure 8 ). The modulus of elasticity of plywood treated with ammonium sulphate remained almost constant at all concentration values for poplar, up to $8 \%$ for alder and $8.5 \%$ for scots pine. Similar results to ammonium sulphate were obtained in the treatment process with zinc borate in scots pine plywood (Figure 9)

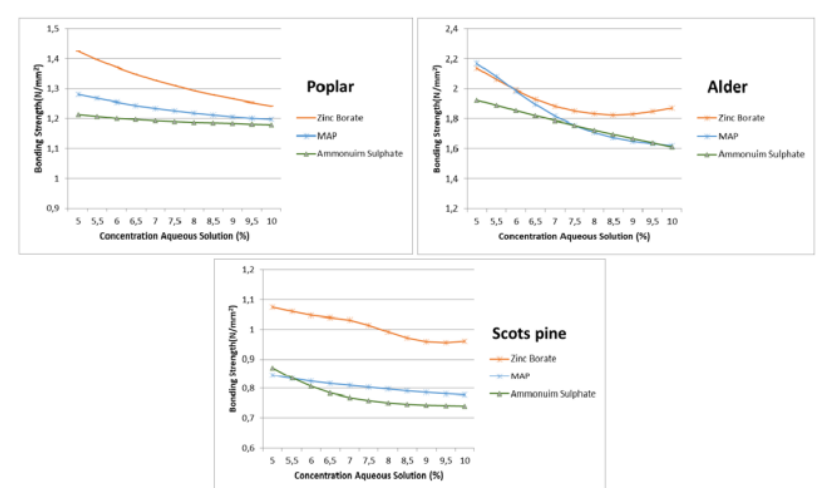

Figure 7. The change of bonding strength with increasing concentration of aqueous solution.

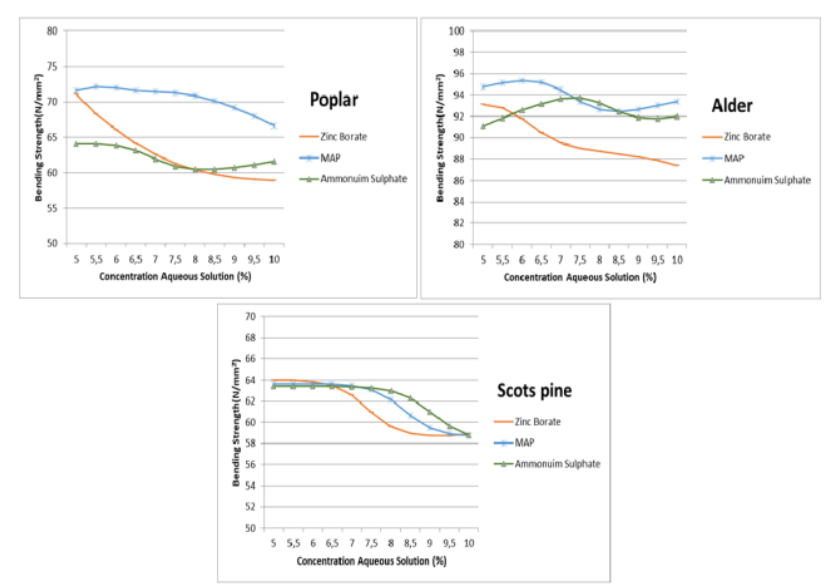

Figure 8. The change of bending strength with increasing concentration of aqueous solution.

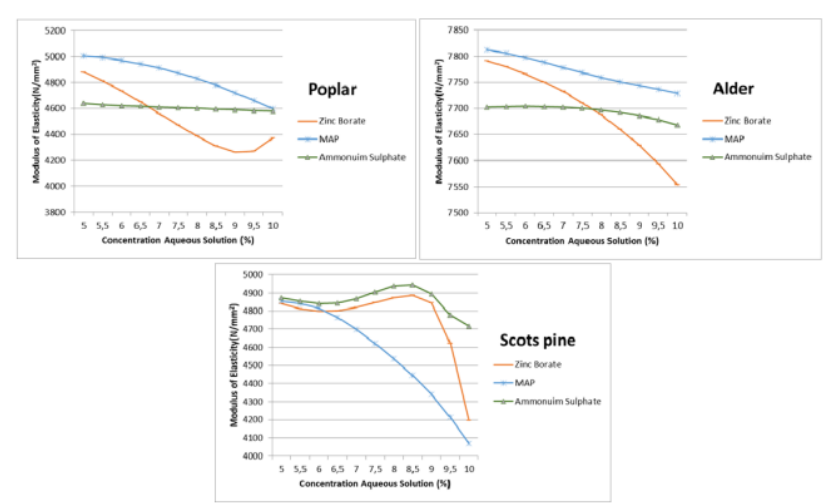

Figure 9. The change of modulus of elasticity with increasing concentration of aqueous solution.

At ANN design, some experimental results were used for training and some others were used for testing (Table 1 and 2). On the other hand, some data values for the poplar samples treated at $7 \%$ concentration of aqueous solution with zinc borate was not available in training set. However, the strength values for this concentration and fire-retardant chemical was available for alder samples (Table 2). It was stated in literature that, ANNs are capable of processing information in a parallel distributed manner, learning complex cause and effect relationships between input and output data, dealing with nonlinear problems, generalizing from known tasks or examples to unknown tasks. ANNs are good for tasks involving incomplete data sets, fuzzy or incomplete information, and for highly complex and illdefined problems for which humans would usually decide on an intuitional basis. Moreover, they can be more adaptable than traditional methods and ANNs technology brings completely different concepts to computing (Ceylan, 2008). As a consequence, the knowledge of the neural network is spread overall the links in network with their weight values. So, the lack of some data in a trained ANN does not significantly affect the network to produce accurate information. 


\section{CONCLUSIONS}

In this study, ANN models were developed to model the effects of wood species and concentration values of aqueous solutions variables on the retention level and the effects of wood species, concentration values of aqueous solutions and retention level variables on mechanical strength values. As a result of the study, the retention level increased with increasing concentration aqueous solution. In generally, mechanical properties of the panels can be adversely influenced by increased concentrations of fireretardants. The different changes of mechanical properties were determined according to concentration of fireretardants in the ANN models. MAPE for retention level, bonding strength, bending strength and modulus of elasticity were $1.014,0.637,1.680$ and $0.418 \%$ for training and 3.416, 2.906, 2.103 and $1.607 \%$ for testing, respectively. RMSE for retention level, bonding strength, bending strength and modulus of elasticity were 0.230 , $0.010,1.364$ and 47.52 for training and 0.602, 0.059, 1.717 and 97.516 for testing, respectively. It can be concluded from this study that the ANN method is reasonable for the modelling (the optimization) of retention level, bonding strength, bending strength and modulus of elasticity at various concentration without needing the experimental study again and again.

\section{ACKNOWLEDGMENTS}

In this study, the experimental results obtained from the study of Demir et al. (2016) were used. Therefore, the authors acknowledge Dr. Aydin Demir, Dr. Ismail Aydin, and Dr. Semra Colak for enabling data to be used. This study was presented in ORENKO 2020 held by Karadeniz Technical University, Trabzon.

\section{REFERENCES}

Aydin, I. (2004). Effects of Some Manufacturing Conditions on Wettability and Bonding of Veneers Obtained from Various Wood Species. PhD Thesis, KTU Natural Science Institute, Trabzon.

Ceylan, I. (2008). Determination of Drying Characteristics of Timber by Using Artificial Neural Networks and Mathematical Models. Drying Technology, 26(12), 1469-1476.

Cheng, R. X. \& Wang, Q. W., (2011). The influence of FRW-1 fire-retardant treatment on the bonding of plywood. Journal of Adhesion Science and Technology, 25, 1715-1724.

Demir, A., Aydin, I. \& Colak, S. (2016). Effect of various fire-retardant chemicals in different concentrations on mechanical properties of plywood. In Proc. $2^{\text {nd }}$ International Furniture Congress, Muğla, Turkey, 13-15 October, $411 \mathrm{pp}$.

Demirkir, C., Özsahin, Ş., Aydin, I. \& Colakoglu, G., (2013). Optimization of some panel manufacturing parameters for the best bonding strength of plywood. International Journal of Adhesion and Adhesives, 46, 14-20.

EN 310, (1993). Wood based panels. Determination of modulus of elasticity in bending and of bending strength. European Standard.

EN 314-1, (1998). Plywood-bonding quality-Part1: test methods, European Standard.

Esteban, L.G., Fernandez, F.G. \& Palacios, P., (2011). Prediction of plywood bonding quality using an artificial neural network. Holzforschung, 65(2), 209-214.

Fateh, T., Rogaume, T., Luche, J., Richard, F \& \& Jabouille, F., (2013). Kinetic and mechanism of the thermal degradation of a plywood by using thermogravimetry and Fourier-transformed infrared spectroscopy analysis in nitrogen and air atmosphere. Fire Safety Journal, 58, 25-37.

Fernández, F.G., Esteban, L.G., Palacios, P., Navarro, N. \& Conde, M. (2008). Prediction of standard particleboard mechanical properties utilizing an artificial neural network and subsequent comparison with a multivariate regression model. Investigación agrarian. Sistemas y Recursos Forestales, 17(2), 178-187.

He, X., Li, X., Zhong, Z., Yan, Y., Mou, Q., Yao, C. \& Wang, C., (2014). The fabrication and properties characterization of wood-based flame retardant composites. Journal of Nanomaterials, Article ID $878357,6 \mathrm{p}$.

Ozkaya, K., Ilce, C.A., Burdurlu, E. \& Aslan, S. (2007). The effect of potassium carbonate, borax and wolmanit on the burning characteristics of Oriented Strand Board(OSB). Construction and Building Materials, 1457-1462.

Ozsahin, S. \& Aydin, I.,(2014). Prediction of the optimum veneer drying temperature for good bonding in plywood manufacturing by means of artificial neural network. Wood science and technology, 48(1), 5970.

Stevens, R., Es, D.S., Bezemer, R. \& Kranenbarg, A. (2006). The structure-activity relationship of fireretardant phosphorus compounds in wood. Polymer Degradation and Stability, 91, 832-841.

Yao, C.H., Wu, Y.Q. \& Hu, Y.C. (2012). Flame-retardation characteristics and mechanisms of three inorganic magnesium compounds as fire-retardant for wood. Journal of Central South University of Forestry and Technology, 32(1), 18-23. 